\title{
Advanced Head and Neck Squamous Cell Carcinoma
}

National Cancer Institute

\section{Source}

National Cancer Institute. Advanced Head and Neck Squamous Cell Carcinoma. NCI

Thesaurus. Code C139291.

A head and neck squamous cell carcinoma that has spread extensively to other anatomical sites or is no longer responding to treatment. 